\title{
DZIALANIA POLSKI NA RZECZ AKTYWIZACJI DIALOGU UNII EUROPEJSKIEJ Z BIAEORUSIĄ W LATACH 2007-2010
}

\author{
Poland's Efforts to Resume the European Union's Dialogue \\ with Belarus between 2007 and 2010
}

In the face of tensions in Belarusian-Russian economic relations in 2007, the European Union (EU) took an attempt to dialogue with the undemocratic authorities of Belarus. The ambition of Donald Tusk's cabinet established in November 2007 was to intensify this process. The government adopted the view that by minimising contacts with Belarus, the West supported its entry into the Russian sphere of influence. Polish diplomats suggested that the dialogue between the EU and Minsk should be conditional. This policy was to offer specific benefits to Belarus in exchange for a gradual democratisation of its internal system. In 2008, the EU adopted this policy. The EU dialogue with Belarus lasted until mid-December 2010. The Belarusian authorities did not fulfil the basic condition of Brussels at that time, which was to hold presidential elections in accordance with the rules of democracy. Minsk's attitude should be explained by a breakthrough in its relations with Moscow. Ten days before the planned elections, the presidents of Belarus and Russia concluded economic agreements favourable for the Belarusian side. The failure of the conditionality policy implemented by the EU with the participation of Poland revealed the weakness of EU instruments in the rivalry with Moscow for influence in the post-Soviet area.

Keywords: Belarus, Polish foreign policy, eastern policy of the EU. 


\section{WPROWADZENIE}

Zgodnie $z$ postanowieniami traktatu $z$ Maastricht, jednym $z$ zadań utworzonej na jego mocy w 1993 roku Unii Europejskiej (UE) stało się prowadzenie Wspólnej Polityki Zagranicznej i Bezpieczeństwa. Po Europejskiej Wspólnocie Gospodarczej UE oddziedziczyła nawiązane relacje $z$ państwami powstałymi w wyniku rozpadu ZSRR. Jednym $z$ trudniejszych partnerów Wspólnoty na obszarze postradzieckim okazała się Białoruś. W 1994 roku urząd prezydenta tego państwa objął Aleksander Łukaszenko. Priorytetem prowadzonej przez niego polityki zagranicznej stało się zacieśnianie relacji $z$ Rosją. W kraju prezydent stopniowo wprowadzał system rządów autorytarnych. W połowie lat dziewięćdziesiątych UE stanęła przed wyzwaniem ukształtowania relacji $z$ państwem rządzonym $\mathrm{w}$ sposób niedemokratyczny, naruszajacym prawa człowieka oraz niezainteresowanym polityczna współpraca z Zachodem. Przyjęta ostatecznie przez Wspólnotę strategia zakładała izolację Mińska. Jej przejawem stały się sankcje wizowe nakładane na przedstawicieli białoruskich wład $^{1}$ oraz wykluczenie tego państwa $z$ ustanowionej w 2004 roku Europejskiej Polityki Sąsiedztwa.

Przystępując w 2004 roku do UE, Polska wykazywała ambicje uzyskania pozycji lidera $\mathrm{w}$ tworzeniu polityki Wspólnoty wobec państw obszaru postradzieckiego. Celem niniejszego artykułu jest zaprezentowanie roli, jaka odegrała Warszawa w kształtowaniu relacji UE z Białorusią w latach 2007-2010. Główne pytanie badawcze dotyczy tego, jakim interesom miała służyć współtworzona przez Polskę polityka oraz czy przyniosła ona zamierzone efekty.

\section{POLSKA WOBEC DIALOGU UNII EUROPEJSKIEJ $Z$ BIAEORUSIA}

W 2007 roku w stosunkach unijno-białoruskich ujawniły się symptomy przełomu. Na Białorusi doszło wówczas do serii wizyt europejskich urzędników wysokiego szczebla². W odbywającej się

1 A. Stępień-Kuczyńska, M. Słowikowski, Unia Europejska a państwa Europy Wschodniej, Warszawa 2008, s. 148.

2 J. Ziankowicz, Z. Parafianowicz, Lukaszenka rozmawia z Unia, „Dziennik. Polska Europa Świat”, 19 I 2007, nr 16, s. 10; A. Poczobut, RICZ, Białoruś mniej izolowana, „Gazeta Wyborcza”, 19 I 2007, nr 16, s. 10; RAD, UE bardziej elastyczna wobec Białorusi? „Tydzień na Wschodzie”, 14 III 2007, nr 1, s. 7. 
w Brukseli 3 września tegoż roku międzynarodowej konferencji na temat wspólpracy UE $z$ państwami sąsiedzkimi w charakterze obserwatora uczestniczył wiceminister spraw zagranicznych Waleryj Waraniecki ${ }^{3}$. Przyczyna zaistniałej zmiany stały się poważne napięcia w relacjach Białorusi z Rosją. W 2007 roku Moskwa podwoiła stawkę, jaką Mińsk musiał uiszczać za gaz ziemny, oraz zadecydowała o stopniowym podwyższaniu opłat za ropę naftowa do poziomu cen światowych ${ }^{4}$. Utrata preferencyjnych warunków dostaw surowców energetycznych groziła Białorusi znaczacym pogorszeniem sytuacji ekonomicznej ${ }^{5}$. Utrzymanie obniżonych stawek za ropę naftową oraz gaz ziemny Moskwa uzależniała od przejęcia kontroli nad białoruska gospodarka przez rosyjski kapitał ${ }^{6}$. W obliczu takich zagrożeń władze Białorusi zaczęły sondować możliwość nawiązania bliższej współpracy $z$ Zachodem ${ }^{7}$.

W rozpoczęty dialog UE $z$ Białorusia postanowił wpisać się powołany w listopadzie 2007 roku rząd Platformy Obywatelskiej (PO) oraz Polskiego Stronnictwa Ludowego (PSL), na którego czele staną Donald Tusk. Głównym realizatorem polityki zagranicznej koalicji został Radosław Sikorski, piastujący w niej stanowisko szefa resortu dyplomacji ${ }^{8}$. Wyznacznikiem jego działalności stał się program $\mathrm{PO}^{9}$.

J. Bielecki, Unia chce oswoić Białoruś, „Dziennik. Polska Europa Świat”, 4 IX 2007, nr 206, s. 16.

${ }^{4}$ I. Topolski, Polityka Federacji Rosyjskiej wobec państw Europy Wschodniej, Lublin 2013, s. 279-280.

A. Eberhardt, Konsekwencje rosyjsko-białoruskiego sporu energetycznego, „Biuletyn Polskiego Instytutu Spraw Międzynarodowych”, 18 I 2007, nr 4, s. 1737-1738; idem, Problematyka energetyczna w stosunkach Federacji Rosyjskiej i Republiki Białoruś, w: Geopolityka rurociagów. Współzależność energetyczna a stosunki międzypaństwowe na obszarze postsowieckim, red. E. Wyciszkiewicz, Warszawa 2008, s. 90.

6 Ł. Adamski, Propozycja nowej strategii UE wobec Białorusi, „Biuletyn Polskiego Instytutu Spraw Międzynarodowych", 25 IX 2008, nr 46, s. 1929.

7 P. Kościński, Po co patrzyć na Zachód wilkiem, „Rzeczpospolita”, 14 II 2007, nr 38, s. A7; A. Poczobut, Manewry Mińska z Moskwa, „Gazeta Wyborcza”, 19 VI 2006, nr 141, s. 15.

8 Polityk ten w rządzie Kazimierza Marcinkiewicza oraz Jarosława Kaczyńskiego sprawował funkcje ministra obrony narodowej. W lutym 2007 r. złożył rezygnację z zajmowanego stanowiska. Od tego czasu stał się zagorzałym krytykiem PiS. Postawa ta spotkała się $z$ uznaniem w szeregach $\mathrm{PO}$, które udzieliło poparcia jego kandydaturze w wyborach parlamentarnych. W grudniu 2008 r. Radosław Sikorski został członkiem PO. W marcu 2008 r. wszedł do zarządu krajowego tej partii, natomiast w październiku 2010 r. został jej wiceprzewodniczącym. Zob. A. Dudek, Historia polityczna Polski 1989-2012, Kraków 2013, s. 602; A. Orzelska-Straczek, Ministrowie spraw zagranicznych w latach 2005-2014. Stefan Meller Anna Fotyga Radosław Sikorski, Warszawa 2016, s. 84.

9 Jak przekonuje Agnieszka Orzelska-Straczek „premier pozostawił mu [Radosławowi Sikorskiemu] pewien zakres samodzielności w sferze kształtowania polityki zagranicznej, ale ramy tej samodzielności określał program wyborczy partii”. Zob. A. Orzelska-Strączek, Ministrowie spraw zagranicznych..., s. 21. 
Zgodnie $\mathrm{z}$ nim fundamentem międzynarodowej aktywności Polski minister uczynił integrację europejska. W artykule opublikowanym w 2009 roku na łamach „Gazety Wyborczej” stwierdził, iż „coraz bardziej określa [ona] podstawowe zasady polskiej polityki zagranicznej oraz krag najbliższych partnerów i sojuszników"10. Radosław Sikorski prezentował jednocześnie opinię, iż Warszawa powinna brać aktywny udział w definiowaniu celów UE. Uzyskanie wpływu na podejmowane w jej ramach decyzje wymagało, według niego, „wczucia się w interes zbiorowości unijnej i utożsamienia się $z$ nim" ${ }^{11}$. Stawiając sobie takie ambicje, Warszawa nie mogła pozostać na uboczu prowadzonej przez Wspólnotę polityki zagranicznej, w tym rozwijającego się dialogu z Mińskiem.

Ożywienie kontaktów unijno-białoruskich uznano w rządzie Donalda Tuska oraz jego politycznym zapleczu za zgodne $z$ interesami Polski. Zauważano bowiem, iż odpowiadając na naruszanie standardów demokracji zerwaniem kontaktów z Białorusią, Zachód sprzyjał wchodzeniu tego państwa do rosyjskiej strefy wpływów ${ }^{12}$. Za priorytet działań, jakie Polska powinna prowadzić wobec swego sąsiada, w środowisku PO uznawano utrzymanie jego niepodległości ${ }^{13}$. W koncepcji polityki zagranicznej wobec Białorusi realizowanej przez Radosława Sikorskiego dostrzegalne było nieartykułowane wprost założenie, iż osoba, która mogła zapewnić temu państwu niezależność, był Aleksander Łukaszenko. Szef resortu dyplomacji zaproponował rezygna-

${ }^{10}$ R. Sikorski, Lekcje historii, modernizacja i integracja, „Gazeta Wyborcza”, 29-30 VIII 2009, nr 202, s. 6.

${ }^{11}$ Sprawozdanie stenograficzne z 15. posiedzenia Sejmu RP w dn. 7 V 2008, wypowiedź Radosława Sikorskiego.

12 Sprawozdanie stenograficzne z 35. posiedzenia Sejmu RP w dn. 13 II 2009, wypowiedź Radosława Sikorskiego; Sprawozdanie stenograficzne z 64. posiedzenia Sejmu RP w dn. 8 IV 2010, wypowiedź Radosława Sikorskiego; Archiwum Rady Ministrów Kancelarii Prezesa Rady Ministrów, Sekretariat Prezesa Rady Ministrów Donalda Tuska, Rządowe programy współpracy z zagranica, sygn. 1289/1, Założenia polskiej polityki zagranicznej w 2008 r., k. 11; J. Saryusz-Wolski, Unia gra z Mińskiem rozsadnie, rozm. przepr. Z. Parafianowicz, „Dziennik. Polska Europa Świat”, 29 IX 2008, nr 228, s. 13; R. Sikorski, Nie czekamy na nagrode pocieszenia, rozm. przepr. M. Bober, „Nasz Dziennik” 31 X - 1 XI 2009, nr 256, s. 8; Kancelaria Sejmu, Biuletyn nr 2747/VI z posiedzenia Komisji Spraw Zagranicznych w dn. 23 IX 2009, wypowiedź Radosława Sikorskiego.

${ }^{13}$ P. Zalewski, Nie oddawać Białorusi walkowerem, „Rzeczpospolita”, 11 I 2007, nr 9, s. A9; Kancelaria Sejmu, Biuletyn $\mathrm{nr} 1390 / \mathrm{V}$ z posiedzenia Komisji Spraw Zagranicznych w dn. 8 XII 2006, wypowiedź Pawła Zalewskiego; Kancelaria Sejmu, Biuletyn nr 3632/VI z posiedzenia Komisji Spraw Zagranicznych w dn. 7 IV 2010, wypowiedź Radosława Sikorskiego; Kancelaria Sejmu, Biuletyn nr 3329/VI z posiedzenia Komisji Łączności z Polakami za Granica w dn. 22 I 2010, wypowiedź Jana Borkowskiego; Kancelaria Sejmu, Biuletyn nr 1227/VI z posiedzenia Komisji Spraw Zagranicznych oraz Komisji Łączności z Polakami za Granica w dn. 2 X 2008, wypowiedź Andrzeja Kremera. 
cję z prowadzonej dotąd przez Polskę polityki mającej na celu wpływanie na wymianę osób sprawujących władzę na Białorusi, na rzecz podjęcia próby zyskania ich przychylności dla Europy ${ }^{14}$. Według Sikorskiego, „niepodległość Białorusi będzie tym bardziej trwała, im bardziej Białoruś otworzy się na Europę"15. Zdominowany przez PO gabinet za metodę wsparcia europejskiej orientacji białoruskich władz uznał nawiązanie $z$ nimi bezpośrednich relacji ${ }^{16}$.

\section{WKŁAD POLSKI W REALIZACJE POLITYKI WARUNKOWEGO DIALOGU}

W kierowanym przez Sikorskiego resorcie założono, iż podejmując próbę dialogu ze wschodnim sąsiadem, Warszawa włączała się w zainicjowana we Wspólnocie politykę, zyskując tym samym wpływ na jej kształt ${ }^{17}$. Od początku kadencji celem gabinetu Tuska stało się zintensyfikowanie unijno-białoruskich kontaktów. Polscy dyplomaci proponowali przy tym, aby dialog Wspólnoty z Mińskiem odbywał się pod pewnymi warunkami. Postulowana przez nich strategia zakładała uzależnienie współpracy $z$ Białorusią od respektowania przez jej władze standardów demokracji ${ }^{18}$. Polityka warunkowości miała polegać na oferowaniu Białorusi konkretnych korzyści w zamian za stopniowa liberalizacje jej wewnętrznego systemu. Zgodnie $z$ oczekiwaniami polskiego rządu w 2008 roku UE przyjęła właśnie tak zdefiniowana politykę ${ }^{19}$.

${ }^{14}$ Kancelaria Sejmu, Biuletyn nr 611/VI z posiedzenia Komisji Spraw Zagranicznych w dn. 6 V 2008, wypowiedź Radosława Sikorskiego.

15 Kancelaria Sejmu, Biuletyn nr 3632/VI, wypowiedź Radosława Sikorskiego.

16 Kancelaria Sejmu, Biuletyn nr 2747/VI, wypowiedź Radosława Sikorskiego; Sprawozdanie stenograficzne z 29. posiedzenia Sejmu RP w dn. 20 XI 2008, wypowiedź Ryszarda Schnepfa i Donalda Tuska; Komunikat MSZ z 22 X 2008, Spotkanie ministra spraw zagranicznych Radosława Sikorskiego z przedstawicielami białoruskiej opozycji demokratycznej, http://www.msz.gov.pl/Spotkanie,Ministra,Spraw,Zagranicznych,Pana,Radoslawa,Sikor skiego,z,przedstawicielami,bialoruskiej,opozycji,demokratycznej,22457.html [dostęp: 12 czerwca 2011].

17 Sprawozdanie stenograficzne z 61. posiedzenia Sejmu RP w dn. 18 II 2010, wypowiedź Jana Borkowskiego; Kancelaria Sejmu, Biuletyn nr 3329/VI, wypowiedź Jana Borkowskiego.

18 Komunikat MSZ z 23 I 2008, Komunikat dotyczacy spotkania ministra spraw zagranicznych Radosława Sikorskiego $z$ ambasadorem Białorusi w Polsce Pawłem tatuszka, http://www.msz.gov.pl/Komunikat,dot., spotkania,Ministra,Spraw,Zagranicznych,Pana, Radoslawa,Sikorskiego,z,Ambasadorem,,Bialorusi,w,Polsce,Panem,Pawlem,Latuszka, 1381 5.html [dostęp: 12 czerwca 2011].

19 W. Lorenz, Mińsk pełznie w stronę Unii, „Rzeczpospolita”, 26 IX 2008, nr 226, s. A12; Ł. Adamski, Propozycja nowej..., s. 1930. 
Bruksela jako podstawowy warunek rozwoju wzajemnych relacji uznała uwolnienie więźniów politycznych. W styczniu i lutym 2008 roku władze Białorusi zezwoliły na przedterminowe wypuszczenie części z nich ${ }^{20}$. Pozostali odzyskali wolność w sierpniu 2008 roku $^{21}$. Gest ten został doceniony przez UE, która już we wrześniu zamierzała wznowić kontakty $z$ Białorusią $\mathrm{w}$ dziedzinie energii, nauki i gospodarki. Nawiązanie relacji na najwyższym szczeblu Bruksela uzależniała natomiast od przebiegu przypadajacych w 2008 roku wyborów parlamentarnych ${ }^{22}$. 6 września 2008 roku podczas nieformalnego szczytu szefów dyplomacji państw UE w Awinionie, Sikorski wystąpił $z$ propozycja przerwania izolacji białoruskich władz jeszcze przed zaplanowanym na koniec miesiaca głosowaniem ${ }^{23} . Z$ informacji prasowych wynikało, iż polska delegacja starała się przekonać unijnych partnerów do złożenia Białorusi oferty współpracy, która zrównoważyłaby straty, jakie miała ona ponieść, w wyniku zwiększenia ceny dostaw gazu ziemnego $z$ Rosji. Zapowiadana przez Moskwę podwyżka wynikała $z$ odmowy uznania przez Mińsk niepodległości Abchazji i Osetii Południowej ${ }^{24}$. Chcąc wesprzeć postawę Białorusi wobec konfliktu rosyjsko-gruzińskiego ${ }^{25}$, europejscy przywódcy wyrazili zgodę

${ }^{20}$ A. Poczobut, Łukaszenko zwalnia politycznych, „Gazeta Wyborcza”, 25 I 2008, nr 21, s. 14; idem, Białoruś. Kolejny polityczny na wolności, „Gazeta Wyborcza”, 28 I 2008, nr 23, s. 11; idem, Białoruś. Wyszedł więzień polityczny, „Gazeta Wyborcza”, 6 II 2008, nr 31, s. 13; kam, Nieznaczne ocieplenie na linii Mińsk-Bruksela, „Tydzień na Wschodzie”, 27 II 2008, nr 8, s. 10-11.

${ }^{21}$ A. Poczobut, Łukaszenka ułaskawił Kazulina, „Gazeta Wyborcza”, 18 VIII 2008, nr 192, s. 9; P. Kościński, Prozachodnia wolta? „Rzeczpospolita”, 18 VIII 2008, nr 192, s. A10. Aleksander Kazulin sam nie prosił o ułaskawienie; A. Poczobut, Łukaszenka uwalnia politycznych, „Gazeta Wyborcza”, 21 VIII 2008, nr 195, s. 9.

${ }^{22}$ J. Bielecki, Zachodnia gra o Białoruś, „Dziennik. Polska Europa Świat”, 22 VIII 2008, nr 196, s. 14; M. Potocki, Łukaszenka wypuścił Kazulina pod presja Zachodu, „Dziennik. Polska Europa Świat", 19 VIII 2008, nr 193, s. 11; MBZ, PAP, UE zniesie sankcje dla Białorusi, „Nasz Dziennik”, 16 IX 2008, nr 217, s. 6.

${ }^{23}$ A. Słojewska, UE łagodniej wobec Mińska, „Rzeczpospolita”, 8 IX 2008, nr 210, s. A10; J. Bielecki, Polski pakiet dla Łukaszenki, „Dziennik. Polska Europa Świat”, 8 IX 2008, nr 210, s. 6; R. Sikorski, Prezydent Lech Kaczyński powinien wziać przykład z brytyjskiej królowej, rozm. przepr. J. Bielecki, „Dziennik. Polska Europa Świat”, 15 IX 2008, nr 216, s. 7.

${ }^{24}$ J. Bielecki, Polski pakiet..., s. 6.

${ }^{25}$ Polscy dyplomaci oraz eurodeputowani od kilku miesięcy podejmowali starania na rzecz złagodzenia polityki Wspólnoty wobec Białorusi. Zgodę europejskich przywódców na zbliżenie $z$ Mińskiem we wrześniu 2008 r. postrzegano w Polsce jako reakcję na wojnę gruzińsko-rosyjska. Przybliżenie Białorusi do UE miało zapobiec odbudowie imperium rosyjskiego. Zob. G. Wierzchołowski, Tusk, tarcza i KGB-Białoruś, „Gazeta Polska”, 16 VII 2008, nr 29, s. 11; J. Bielecki, Nowy kurs: bliżej z Białorusia, „Dziennik. Polska Europa Świat”, 25 VI 2008, nr 147, s. 6; A. Słojewska, P. Kościński, Polski spór o białoruskie sankcje, „Rzeczpospolita”, 28-29 VI 2008, nr 150, s. A10; J. Pawlicki, A. Poczobut, Wyborczy kontrakt z Białorusia, „Gazeta Wyborcza”, 25 IX 2008, nr 225, s. 8; J. Bielecki, Unia murem za Andżelika Borys, „Dziennik. Polska Europa Świat”, 10 X 2008, nr 238, s. 5. 
na wizytę polskiego ministra spraw zagranicznych w tym kraju ${ }^{26}$. Doszło do niej 12 września ${ }^{27}$. Podczas spotkania ze swym białoruskim odpowiednikiem Siargiejem Martynowem, Radosław Sikorski przedstawił unijną propozycję. Zakładała ona rozwój relacji gospodarczych oraz zniesienie sankcji nałożonych na przedstawicieli białoruskich władz. Realizację tej oferty Bruksela warunkowała zapewnieniem możliwości funkcjonowania na Białorusi opozycji oraz niezależnych mediów. Jako podstawowy wyznacznik intencji Mińska UE uznała demokratyczny przebieg wyborów parlamentarnych zaplanowanych na koniec września 2008 roku $^{28}$.

W tym czasie na Białorusi nastapiła pewna liberalizacja procesu wyborczego. Oceniając przygotowania do wyborów parlamentarnych, przedstawiciele UE nie mieli jednak złudzeń, iż można będzie je uznać za demokratyczne. Bruksela domagała się od białoruskich władz zapewnienia przynajmniej ich częściowo wolnego przebiegu. Zgodnie $z$ oczekiwaniami zachodnich przywódców, w parlamencie powinna się znaleźć reprezentacja sił opozycyjnych, złożona $z$ powszechnie znanych działaczy, a nie przedstawicieli opozycji koncesjonowanej ${ }^{29}$. Na kilka dni przed zaplanowanym terminem głosowania $\mathrm{w}$ polskiej prasie pojawiły się informacje, $z$ których wynikało, iż UE przekazała białoruskim władzom listę $z$ nazwiskami około 20 polityków, którzy mieli otrzymać miejsca w parlamencie. Uzyskanie przez nich mandatów stanowiłoby gest ze strony Mińska pozwalający na wprowadzenie w życie przedstawionej przez Radosława Sikorskiego unijnej oferty ${ }^{30}$. Według doniesień prasowych w poufnych rozmowach $z$ białoruskimi władzami, jak też opozycjonistami, aktywnie uczestniczyli przedstawiciele Polski ${ }^{31}$.

${ }^{26}$ J. Bielecki, Sikorski z ofertą dla Mińska, „Dziennik. Polska Europa Świat”, 13-14 IX 2008, nr 215, s. 3; KRYST, Unijne otwarcie na Białoruś, „Trybuna”, 15 IX 2008, nr 216, s. 3.

27 Komunikat MSZ z 12 IX 2008, Wizyta ministra spraw zagranicznych Radosława Sikorskiego w Republice Białoruś, http://www.msz.gov.pl/Wizyta,Ministra,Spraw,Zagrani cznych,Pana,Radoslawa,Sikorskiego,w,Republice,Bialorus,21576.html [dostęp: 12 czerwca 2011].

28 J. Bielecki, Sikorski z ofertą..., s. 3. Zob. też Z. Parafianowicz, A. Ciechanowicz, Czy Łukaszenka podzieli się władza, „Dziennik. Polska Europa Świat”, 31 VII 2008, nr 178, s. 1; A. Słojewska, P. Kościński, Polski spór..., s. A10.

29 W. Lorenz, Mińsk pełznie..., s. A12. Zob. też Z. Parafianowicz, A. Ciechanowicz, Czy Łukaszenka..., s. 1 .

30 P. Kościński, W. Lorenz, Tajna gra Unii z Białorusia, „Rzeczpospolita”, 27-28 IX 2008, nr 227, s. A8; J. Pawlicki, A. Poczobut, Wyborczy kontrakt..., s. 8.

31 J. Pawlicki, A. Poczobut, Europa negocjuje z Łukaszenka. Polska żyruje, „Gazeta Wyborcza", 25 IX 2008, nr 225, s. 1. 
Obecni na Białorusi obserwatorzy OBWE przebieg wyborów ocenili jako niespełniający wymogów demokratycznego głosowania ${ }^{32}$. Zgodnie $z$ oficjalnymi wynikami, żaden $z$ opozycyjnych kandydatów nie uzyskał wystarczającej liczby głosów, pozwalającej na wejście do parlamentu ${ }^{33}$. W odczuciu kierowanego przez Sikorskiego MSZ nie stanowiło to jednak klęski współtworzonej przez Polskę unijnej strategii. Tłumaczono, iż nikt nie liczył na natychmiastowa poprawę standardów demokracji ${ }^{34}$. Dyplomaci oficjalnie przekonywali, iż nie było żadnego przedwyborczego porozumienia $z$ Łukaszenką, które zostałoby złamane ${ }^{35}$. W środowisku wspierajacym politykę dialogu wina za rezultat wyborczy obciążano nie tylko białoruskie władze, ale też samą opozycję. Eurodeputowany PO Jacek Saryusz-Wolski, komentując przebieg wyborów, stwierdził: „Możliwe, że [...] nieobecność [opozycji] w parlamencie to rezultat sfałszowanych wyborów, ale powodem może być też jej słaba siła przekonywania" ${ }^{36}$.

Mimo negatywnej oceny wyborów parlamentarnych polski resort dyplomacji, jak też politycy PO uznali, iż UE powinna docenić pozytywne zjawiska, jakie miały miejsce na Białorusi $\mathrm{w}$ ostatnich miesiącach. Podkreślano zwłaszcza fakt wypuszczenia więźniów politycznych oraz umożliwienie zachodnim obserwatorom monitorowania przebiegu wyborów parlamentarnych. Wydarzenia te uznano za dostateczny powód kontynuowania polityki otwarcia zakładajaccej nagradzanie wszystkich przejawów liberalizacji ${ }^{37}$. Stanowisko takie znalazło odzwierciedlenie w przyjętej 9 października 2008 roku rezolucji Parlamentu Europejskiego. Jej autorem był eurodeputowany $z$ ramienia PO Jacek Protasiewicz, pełniący funkcję szefa delegacji

${ }^{32}$ ŁS, PAP, OBWE: Mińsk daleki od demokracji, „Nasz Dziennik”, 30 IX 2008, nr 229, s. 7; P. Kościński, W. Lorenz, Unia niezrażona wyborami na Białorusi, „Rzeczpospolita”, 30 IX 2008, nr 229, s. A10; J. Bielecki, Łukaszenka nie przepuścił opozycji, „Dziennik Polska Europa Świat", 30 IX 2008, nr 229, s. 1.

${ }^{33}$ P. Kościński, W. Lorenz, Unia nie zrażona..., s. A10.

${ }^{34}$ M. Wójcik, K. Wronowska, Opozycja chce znać szczegóły planu MSZ, „Dziennik. Polska Europa Świat”, 7 X 2008, nr 235, s. 4; A. Poczobut, Łukaszenka sam wybrał, „Gazeta Wyborcza", 30 IX 2008, nr 229, s. 8.

${ }^{35}$ P. Kościński, pap, afp, Gest wobec Minska, „Rzeczpospolita”, 10 X 2008, nr 238, s. A12.

${ }^{36}$ J. Saryusz-Wolski, Trzeba złagodzić kurs wobec Mińska, rozm. przepr. W. Lorenz, „Rzeczpospolita”, 30 IX 2008, nr 229, s. A10.

${ }^{37}$ P. Kościński, pap, afp, Gest wobec Mińska..., s. A12; J. Saryusz-Wolski, Unia gra z Mińskiem..., s. 13; idem, Trzeba złagodzić kurs..., s. A10; J. Bielecki, Łukaszenka nie przepuścił..., s. 1; Kancelaria Sejmu, Biuletyn nr 1227/VI, wypowiedź Andrzeja Kremera; Kancelaria Sejmu, Biuletyn nr 1339/VI z posiedzenia Komisji Łaczności z Polakami za Granica w dn. 15 X 2008, wypowiedź Andrzeja Kremera; P. Kościński, W. Lorenz, Unia niezrażona..., s. A10. 
ds. Białorusi ${ }^{38}$. Przygotowana przez niego uchwała wzywała Komisje Europejską oraz Radę UE do zawieszenia sankcji wizowych dla większości członków białoruskich władz. Zawierała również propozycję objęcie Białorusi instrumentami EPS, co pozwoliłoby na korzystanie przez nią $z$ funduszy pomocowych ${ }^{39}$.

Dnia 13 października 2008 roku w Luksemburgu, w obecności Siergieja Martynowa ${ }^{40}$, ministrowie spraw zagranicznych UE podjęli decyzję o półrocznym zawieszeniu obowiązywania sankcji wizowych nałożonych na Aleksandra Łukaszenkę oraz 36 innych przedstawicieli władz państwowych. Decyzje o dalszym losie restrykcji miały być podjęte wiosna następnego roku $^{41}$. Grupa eurodeputowanych $z$ Jackiem Protasiewiczem na czele, w porozumieniu $z$ reprezentantami białoruskich sił opozycyjnych, wypracowała listę warunków, od których należało uzależnić dalszy rozwój współpracy UE z Mińskiem ${ }^{42}$. Ustalono, iż na Białorusi musza zostać wprowadzone zmiany w prawie wyborczym oraz karnym. Zniesieniu powinny ulec przepisy pozwalające na legalne represjonowanie opozycji, fałszowanie wyborów oraz ograniczanie wolność mediów. Oczekiwano również od białoruskich władz zapewnienia swobody funkcjonowania organizacji pozarzadowych oraz partii politycznych, jak też umożliwienia druku i dystrybucji niezależnych gazet ${ }^{43}$. Warunki te w całości miały zostać wypełnione do końca 2010 roku, co umożliwiłoby uczciwe przeprowadzenie przypadajacych w 2011 roku wyborów prezydenckich ${ }^{44}$.

${ }^{38}$ J. Bielecki, Ostatnia szansa dla Mińska, „Dziennik. Polska Europa Świat”, 1 X 2008, nr 230, s. 12.

${ }^{39}$ Rezolucja Parlamentu Europejskiego z dn. 9 X 2008 w sprawie sytuacji na Białorusi po wyborach parlamentarnych w dn. 28 IX 2008 r., www.europarl.europa.eu [dostęp: 5 marca 2017].

${ }^{40}$ P. Kościński, reuters, afp, Białoruski minister jedzie na spotkanie z Unia, „Rzeczpospolita”, 4-5 X 2008, nr 233, s. A8; kam, UE udziela wsparcia Białorusi, „Tydzień na Wschodzie" 8 X 2008, nr 32, s. 7.

${ }^{41}$ T. Bielecki, Łukaszenka może wjechać do Europy, „Gazeta Wyborcza” 14 X 2008, nr 241, s. 16; agaw, Unia zawiesiła sankcje wizowe wobec Białorusi, „Tydzień na Wschodzie”, 16 X 2008, nr 33, s. 11.10 listopada 2008 r. Rada przyjęła stanowisko o przedłużeniu o rok obowiazywania sankcji wizowych wobec niektórych urzędników białoruskich. Jednocześnie realizację tej sankcji zawieszono na 6 miesięcy. Zawieszeniu nie podlegały sankcje wizowe nałożone na osoby zamieszane $\mathrm{w}$ zaginięcia polityków i dziennikarzy $\mathrm{w}$ latach 1999-2000 oraz na przewodnicząca Centralnej Komisji Wyborczej Lidziję Jarmoszynę. Zob. T. Kubin, Stosunki polsko-białoruskie w końcu XX i na poczatku XXI wieku, w: Stosunki Polski z sasiadami w pierwszej dekadzie XXI wieku, red. M. Stolarczyk, Katowice 2011, s. 179.

${ }^{42}$ J. Bielecki, Ostatnia szansa..., s. 12; agaw, Głos opozycji $w$ dialogu UE z władzami Białorusi, „Tydzień na Wschodzie”, 5 XI 2008, nr 36; J. Pawlicki, A. Poczobut, Unia nęci Eukaszenke, „Gazeta Wyborcza”, 30 X 2008, nr 255, s. 10.

${ }^{43}$ Rezolucja Parlamentu Europejskiego z dn. 15 I 2009 w sprawie strategii UE wobec Białorusi, www.europarl.europa.eu [dostęp: 8 marca 2017].

${ }^{44}$ J. Bielecki, Ostatnia szansa..., s. 12. 
W kolejnych miesiącach na Białorusi zauważalna była pewna liberalizacja. Pod koniec listopada 2008 roku Mińsk umożliwił dystrybucje dwóch niezależnych gazet ${ }^{45}$. W grudniu władze zgodziły się na rejestrację ruchu O Wolność ${ }^{46}$. Na jego czele stał Aleksander Milinkiewicz - główny konkurent Aleksandra Łukaszenki w wyborach prezydenckich w 2006 roku. Przedstawiciele opozycji dopuszczeni zostali do rad konsultacyjnych zajmujących się kwestiami zwiąanymi ze społeczno-politycznym rozwojem kraju, mediami oraz prawami człowieka $^{47}$. Na Białorusi miały jednak równocześnie miejsce wydarzenia sprzeczne $z$ oczekiwaniami UE. W lutym 2009 roku do aresztu trafiło dwóch opozycjonistów, którzy kilka miesięcy wcześniej w ramach odwilży zostali wypuszczeni $z$ więzienia ${ }^{48}$. Dochodziło również do przypadków wykluczania młodych działaczy ugrupowań antyrzadowych $z$ życia politycznego poprzez kierowanie ich do wojska ${ }^{49}$. W lutym w Mińsku został brutalnie rozpędzony wiec opozycji ${ }^{50}$. Parlament Europejski, dokonujac analizy sytuacji w tym państwie w połowie okresu trwania moratorium, przypominał, iż na rejestrację wciąż oczekiwało 13 niezależnych gazet, natomiast wypuszczeni na wolność więźniowie polityczni „nie korzystaja ze wszystkich praw gwarantowanych obywatelom białoruskim w Konstytucji Republiki Białorusi”"51.

Mimo braku istotnych postępów białoruskich władz $\mathrm{w}$ działaniach na rzecz demokratyzacji UE nie rezygnowała $z$ polityki dialogu. Oceniając, iż Białoruś niedostatecznie wypełniała stawiane jej warunki, w marcu 2009 roku Rada UE podjęła decyzję o przedłużeniu obowiazywania sankcji wizowych o kolejny rok. Jednocześnie jednak w zawieszeniu na 9 miesięcy utrzymała ich wykonanie ${ }^{52}$. Identycz-

45 A. Poczobut, Troszkę więcej wolności dla białoruskich mediów, „Gazeta Wyborcza”, 29-30 XI 2008, nr 279, s. 11.

${ }^{46}$ Idem, Łukaszenka legalizuje opozycje, „Gazeta Wyborcza”, 18 XII 2008, nr 295, s. 8.

47 Idem, Opozycja doradzi Łukaszence, "Gazeta Wyborcza”, 28 I 2009, nr 23, s. 9; A. Pisalnik, Opozycja pomoże Łukaszence, „Rzeczpospolita”, 29 I 2009, nr 24, s. A12; agaw, Białoruś: Kolejne próby poprawy wizerunku reżimu, „Tydzień na Wschodzie”, 28 I 2009, nr 4, s. 12.

48 A. Poczobut, Białoruś: Polowanie na politycznych, „Gazeta Wyborcza”, 9 II 2009, nr 33, s. 11; agaw, Białoruś: Przygotowania do politycznego procesu, „Tydzień na Wschodzie", 18 II 2009, nr 7, s. 12-13.

49 A. Pisalnik, Białoruś: opozycjoniści ida do wojska, „Rzeczpospolita”, 30 I 2009, nr 25, s. A12; agaw, Białoruś: Represje wobec młodych opozycjonistów, „Tydzień na Wschodzie”, 4 II 2009, nr 5, s. 11.

${ }^{50}$ PAP, Białoruś. Skopana opozycja, „Gazeta Wyborcza”, 17 II 2009, nr 40, s. 11.

${ }^{51}$ Rezolucja Parlamentu Europejskiego z dn. 15 I 2009.... Zob. też A. Słojewska, Metoda kija i marchewki wobec Białorusi, „Rzeczpospolita”, 16 I 2009, nr 13, s. A11.

52 A. Słojewska, Unijna marchewka dla Mińska, „Rzeczpospolita”, 17 III 2009, nr 64, s. A9; D. Pszczółkowska, Europa nagradza Łukaszenkę, „Gazeta Wyborcza”, 17 III 2009, 
nego zabiegu dokonała 17 listopada 2009 roku $^{53}$. Decyzje te pozwalały na podejmowanie dyplomatycznych kontaktów $z$ białoruskimi władzami.

Kontynuowany $\mathrm{w}$ kolejnych miesiącach dialog Brukseli z Mińskiem wciąż miał charakter warunkowy. W unijnej ofercie zawarto: możliwość popisania umowy o partnerstwie i współpracy, pomoc finansowa, preferencje handlowe, podjęcie negocjacji dotyczacych przystapienia Białorusi do Światowej Organizacji Handlu, jak też dostęp do projektów przewidzianych w ramach Partnerstwa Wschodniego ${ }^{54}$. $\mathrm{Na}$ początku 2010 roku Europejski Bank Inwestycyjny zapowiedział możliwość udzielenia Białorusi kredytów o wartości kilkuset milionów euro ${ }^{55}$. Realizację tych propozycji uzależniano od tempa dokonywanych przez białoruskie władze wewnętrznych przeobrażeń. Wśród konkretnych żądań, oprócz sformułowanych wcześniej, pojawiało się m.in. zapewnienie możliwości swobodnego funkcjonowania zagranicznych mediów oraz zaprzestanie wykonywania kary śmierci ${ }^{56}$.

Jako podstawowy warunek rozwoju współpracy z Mińskiem Bruksela traktowała jednak poprawę jakości procesu wyborczego. W 2010 roku białoruskie władze faktycznie dokonały korekty obowiazujaccej dotąd ordynacji. Pierwszym testem liberalizacji przepisów miały być przypadające na kwiecień tego roku wybory samorządowe ${ }^{57}$. Zgodnie $z$ oczekiwaniami UE zmianie uległy zasady tworzenia komisji wyborczych. Według nowej ordynacji, przynajmniej jedna trzecia ich składu miała rekrutować się $z$ przedstawicieli partii politycznych oraz organizacji społecznych ${ }^{58}$. Podczas wyborów samorządowych wymóg

nr 64, s. 10; agaw, UE przedłuża zawieszenie sankcji wobec Białorusi, „Tydzień na Wschodzie”, 18 III 2009, nr 11, s. 9-10.

53 PAP, Przedłużone i zawieszone, „Trybuna”, 18 XI 2009, nr 270, s. 7; dyn, Sankcje UE wobec Białorusi pozostana zamrożone, „Tydzień na Wschodzie”, 18 XI 2009, nr 39, s. $11-12$.

${ }^{54}$ Rezolucja Parlamentu Europejskiego z dn. 10 III 2010 w sprawie sytuacji społeczeństwa obywatelskiego i mniejszości narodowych na Białorusi, www.europarl.europa.eu [dostęp: 7 marca 2017].

${ }_{55}$ M. Przydacz, Polityka zagraniczna wobec Białorusi, w: Główne kierunki polityki zagranicznej rządu Donalda Tuska $w$ latach 2007-2011, red. P. Musiałek, Kraków 2012, s. 291-292.

56 Rezolucja Parlamentu Europejskiego z dn. 2 IV 2009 w sprawie oceny dialogu między Unią Europejską a Białorusia, www.europarl.europa.eu [dostęp: 8 marca 2017]; Rezolucja Parlamentu Europejskiego z dn. 17 XII 2009 r. w sprawie Białorusi, www.europarl. europa.eu [dostęp: 7 marca 2017].

57 J. Bielecki, Polska chce od Unii ultimatum dla Mińska, „Dziennik Gazeta Prawna”, 18 II 2010, nr 34, s. A2; A. Słojewska, Kraje Partnerstwa Wschodniego staja po stronie Mińska, „Rzeczpospolita”, 5 III 2010, nr 54, s. A10.

${ }^{58}$ A. Czwołek, Opozycja polityczna na Białorusi (1989-2010), Gdańsk 2013, s. 333. 
ten rzeczywiście został zachowany. W komisjach znaleźli się jednak przede wszystkim reprezentanci organizacji proreżimowych ${ }^{59}$. Członkowie sił antyrządowych stanowili również znikomy odsetek wszystkich zarejestrowanych kandydatów ${ }^{60}$. Realnej poprawie nie uległy warunki prowadzenia kampanii. W kwietniu 2010 roku tradycyjnie wiele kontrowersji wywołało głosowanie przedterminowe. Obserwatorzy międzynarodowi zgłosili też liczne zastrzeżenia dotyczące przebiegu wyborów $\mathrm{w}$ głównym dniu ${ }^{61}$. Zgodnie $z$ oficjalnymi wynikami mandaty $\mathrm{w}$ samorządach uzyskało zaledwie kilku przedstawicieli opozycji ${ }^{62}$.

W ocenie Brukseli przebieg wyborów samorządowych nie spełnił demokratycznych standardów ${ }^{63}$. Mimo to nie zdecydowano się na przerwanie dialogu $z$ białoruskimi władzami ${ }^{64}$. Większe znaczenie UE przywiazywała bowiem do wyborów prezydenckich, które miały odbyć się na początku 2011 roku. We wrześniu 2010 roku Aleksander tukaszenko zadecydował o ich przyśpieszeniu. Termin głosowania został wyznaczony na 19 grudnia 2010 roku $^{65}$. 25 października Rada UE przedłużyła sankcje wizowe wobec 41 przedstawicieli białoruskich władz, jednocześnie utrzymując je w zawieszeniu. Dalsze relacje $z$ tym państwem uzależniono od oceny przebiegu zbliżających się wyborów ${ }^{66}$.

Dnia 2 listopada 2010 roku ze wspólna wizyta do Mińska udali się ministrowie spraw zagranicznych Polski oraz Niemiec. Radosław Sikorski i Guido Westerwelle spotkali się z Siergiejem Martynowem oraz Aleksandrem Łukaszenka ${ }^{67}$. Unijni wysłannicy zaapelowali wówczas o jak najbardziej uczciwy przebieg wyborów prezydenckich ${ }^{68}$.

59 Ibidem, s. 652-653.

60 dyn, Wybory lokalne na Białorusi, „Tydzień na Wschodzie”, 28 IV 2010, nr 16, s. 13.

61 A. Czwołek, Opozycja polityczna..., s. 656-659.

62 dyn, Wybory lokalne..., s. 13.

63 RICZ, PAP, Wyborcza farsa i represje na Białorusi, „Gazeta Wyborcza”, 16 I 2007, nr 13 , s. 9.

64 A. Czwołek, Opozycja polityczna..., s. 758.

65 A. Poczobut, Łukaszenko planuje zwycięstwo w pierwszej turze, „Gazeta Wyborcza”, 15 IX 2010, nr 216, s. 10.

${ }^{66}$ WojK, UE przedłużyła $i$ (ponownie) zawiesiła sankcje wobec Białorusi, „Tydzień na Wschodzie", 27 X 2010, nr 36, s. 9.

67 Komunikat MSZ z 2 XI 2010, Wizyta ministra spraw zagranicznych RP w Mińsku, http://www.msz.gov.pl/Wizyta,Ministra,Spraw,Zagranicznych,RP,w,Minsku,38946.html [dostęp: 12 czerwca 2011].

68 P. Kościński, Sikorski jedzie do Łukaszenki, „Rzeczpospolita”, 30 X - 1 XI 2010, nr 255, s. A9; A. Poczobut, Polsko-niemiecka misja na Białorusi, „Gazeta Wyborcza”, 29 X 2010, nr 254, s. 9; ŁS, PAP, Sikorski apeluje do Mińska o uczciwe wybory, „Nasz Dziennik”, 3 XI 2010, nr 257, s. 7. 
Bruksela zdawała sobie sprawę, iż zasady demokracji naruszane były już podczas tworzenia komisji. Większość osób zgłoszonych do nich przez opozycje nie została bowiem zaakceptowana ${ }^{69}$. Podczas wizyty w Mińsku szefowie dyplomacji Polski i Niemiec próbowali jednak nakłonić białoruskie władze do przeprowadzenia kolejnych etapów procesu wyborczego zgodnie $z$ uznanymi w Europie zasadami ${ }^{70}$. Przypominali, iż o demokratyzacji nie decyduje samo liczenie głosów, ale również stworzenie jednakowych warunków prowadzenia kampanii dla wszystkich kandydatów. W zamian za wyłonienie głowy państwa zgodnie $z$ europejskimi standardami w ciagu trzech lat Białoruś miała otrzymać od UE pomoc w wysokości 3 mld euro ${ }^{71}$. W przypadku sfałszowania wyników głosowania Radosław Sikorski oraz Guido Westerwelle zapowiedzieli powrót Brukseli do polityki sankcji ${ }^{72}$.

\section{ZAKOŃCZENIE POLITYKI WARUNKOWEGO DIALOGU}

Sposób przeprowadzenia wyborów prezydenckich w 2010 roku różnił się od praktyk stosowanych w 2001 oraz 2006 roku. Nowa ordynacja wprowadzała ułatwienia w procedurze rejestracji kandydatów ${ }^{73}$. Ostatecznie zarejestrowanych zostało 10 kandydatów, $z$ czego 7 wywodziło się $z$ opozycji politycznej ${ }^{74}$. Niezależni obserwatorzy ten etap procesu wyborczego ocenili pozytywnie ${ }^{75}$. W porównaniu $z$ rokiem 2006 poprawie uległa możliwość prowadzenia agitacji wyborczej. Kampania nie miała jednak równego charakteru. W środkach masowego przekazu wyraźnie faworyzowany był urzędujący prezydent ${ }^{76}$.

Wybory prezydenckie, według oficjalnych wyników, zdecydowanie wygrał Łukaszenko, otrzymując niemal 80 proc. poparcia. Misja OBWE przebieg wyborów prezydenckich na Białorusi uznała za niedemokratyczny. Wieczorem 19 grudnia w Mińsku doszło do powy-

69 kam, Pozornie pluralistyczna kampania wyborcza na Białorusi, „Tydzień na Wschodzie", 24 XI 2010, nr 39, s. 13.

${ }^{70}$ G. Westerwelle, R. Sikorski, Polska z Niemcami razem dla Wschodu, „Gazeta Wyborcza", 5 XI 2010, nr 259, s. 13.

71 P. Kościński, W. Lorenz, Unijny duet naciska na Łukaszenkę, „Rzeczpospolita”, 3 XI 2010, nr 257, s. A10; A. Poczobut, Trzy miliardy euro za demokracje, „Gazeta Wyborcza”, 3 XI 2010, nr 257, s. 9.

72 Z. Parafianowicz, Ultimatum dla Łukaszenki, „Dziennik Gazeta Prawna”, 3 XI 2010, nr 214, s. A8.

73 A. Czwołek, Opozycja polityczna..., s. 336-337.

74 Ibidem, s. 676.

75 Ibidem, s. 672.

76 Szerzej na temat kampanii wyborczej w 2010 r. zob. ibidem, s. 674-676. 
borczej manifestacji, która została brutalnie stłumiona przez milicję. Setki protestujaccych trafiło do aresztu, w tym wszyscy opozycyjni kandydaci na urzą prezydenta ${ }^{77}$.

Ministrowie spraw zagranicznych Polski oraz Niemiec wystosowali 20 grudnia 2010 roku wspólne oświadczenie w sprawie wydarzeń na Białorusi. Użyta wobec demonstrantów przemoc oraz aresztowanie czołowych opozycjonistów spotkały się z ich stanowczym potępieniem. Stwierdzili również, iż przekazany Łukaszence w listopadzie 2010 roku warunek przeprowadzenia uczciwych wyborów prezydenckich nie został spełniony ${ }^{78}$. W opublikowanym kilka dni później na łamach „The New York Times” artykule ministrowie spraw zagranicznych Polski, Czech, Niemiec oraz Szwecji zapowiedzieli, iż w zaistniałej sytuacji Unia Europejska nie może utrzymywać pozytywnej współpracy $z$ Łukaszenka ${ }^{79}$. Rzeczywiście, unijno-białoruski dialog uległ natychmiastowemu przerwaniu. Od poczatku 2011 roku Wspólnota powróciła do polityki izolacji Mińska.

\section{PODSUMOWANIE}

Podjęta przez UE, przy aktywnym wsparciu Polski, próba dialogu z Mińskiem miała na celu utrzymanie niezależności Białorusi poprzez europeizację jej władz. Prowadzona w latach 2007-2010 polityka zakończyła się niepowodzeniem. Wszystko wskazuje na to, iż niewypełnienie przez prezydenta Białorusi stawianego mu warunku tłumaczyć należy przełomem w jego relacjach $z$ Rosją. Dziesięć dni przed wyborami prezydenckimi Łukaszenko złożył wizytę w Moskwie,

77 A. Poczobut, Łukaszenka pewny, „Gazeta Wyborcza”, 20 XII 2010, nr 296, s. 10; P. Kościński, Wielki atak na opozycję, „Rzeczpospolita”, 21 XII 2010, nr 297, s. A10; M. Wojciechowski, Białoruś pod butem reżimu, „Gazeta Wyborcza”, 21 XII 2010, nr 297, s. 1;

A. Poczobut, Miłosierdzie Łukaszenki, „Gazeta Wyborcza”, 21 XII 2010, nr 297, s. 10;

A. Pisalnik, Łukaszenko więzi swoich rywali, „Rzeczpospolita”, 23 XII 2010, nr 299, s. A11;

A. Poczobut, Ilu rannych jest $w$ Mińsku? „Gazeta Wyborcza”, 24-26 XII 2010, nr 300, s. 10;

P. Kościński, A. Pisalnik, Chca aresztować tysiące opozycjonistów, „Rzeczpospolita”, 24-26 XII 2010, nr 300, s. A12.

78 Komunikat MSZ z 20 XII 2010, Wspólne oświadczenie ministrów spraw zagranicznych Radosława Sikorskiego i Guido Westerwelle w sprawie wydarzeń na Białorusi, http:// www.msz.gov.pl/Wspolne,oswiadczenie,Ministrow,Spraw,Zagranicznych,Radoslawa,Sikors kiego,i,Guido,Westerwelle,w,sprawie,wydarzen,na,Bialorusi,39932.html [dostęp: 12 czerwca 2011].

79 Komunikat MSZ z 24 XII 2010, Wspólny artykuł ministrów spraw zagranicznych Czech, Niemiec, Polski i Szwecji w sprawie Białorusi, http://www.msz.gov.pl/Wspolny, artykul,Ministrow,Spraw,Zagranicznych,Czech,,Niemiec,,Polski,i,Szwecji,w, sprawie,Bialo rusi,40035.html [dostęp: 12 czerwca 2011]; M. Potocki, Łukaszenka opozycji nie odpuszcza, „Dziennik Gazeta Prawna”, 27 XII 2010, nr 251, s. A8; A. Poczobut, Ilu rannych..., s. 10. 
podczas której został przyjęty przez Dmitrija Miedwiediewa. W trakcie spotkania prezydenci osiagnęli porozumienie w kwestii cen gazu i ropy ${ }^{80}$. Podpisane wówczas umowy okazały się bardzo korzystne dla Mińska. W tej sytuacji prezydent stracił zainteresowanie nawiazywaniem bliższych relacji $z$ Zachodem. Prawdziwa okazała się diagnoza analityków Ośrodka Studiów Wschodnich z 2008 roku, którzy przypuszczali, iż „poprawa relacji z Unią Europejska jest Białorusi potrzebna jako argument wzmacniający pozycję Mińska w stosunkach $z$ Moskwa, wobec rosyjskiej polityki nacisków w sferze gospodarki i energetyki" ${ }^{\prime 1}$. Bruksela, podejmujacc dialog $z$ Mińskiem, pokazała gotowość do realizacji inicjatyw korzystnych dla białoruskiej gospodarki. Rosja, w przeciwieństwie do UE, w zamian za gwarancje finansowe nie domagała się jednak od Łukaszenki żadnych działań $\mathrm{w}$ polityce wewnętrznej ${ }^{82}$. Niepowodzenie zapoczątkowanego dialogu ujawniło słabość unijnych instrumentów w prowadzonej z Moskwa rywalizacji o wpływy na obszarze postradzieckim.

${ }^{80}$ A. Poczobut, W. Radziwinowicz, Łukaszenka złamał Rosje, „Gazeta Wyborcza”, 11-12 XII 2010, nr 289, s. 9.

${ }^{81}$ A. Wierzbowska-Miazga, K. Kłysiński, Ożywienie $w$ stosunkach białorusko-unijnych, „Tydzień na Wschodzie”, 12 III 2008, nr 10, s. 5. Zob. też A. Wierzbowska-Miazga, K. Kłysiński, Białoruś - powrót represji, „Tydzień na Wschodzie”, 2 IV 2008, nr 12, s. 4-5; K. Kłysiński, współpr. P. Wołowski, Podwójna gra Aleksandra Łukaszenki, „Tydzień na Wschodzie”, 10 IX 2008, nr 28, s. 7-9; K. Kłysiński, Białoruś: rezultat wyborów nie przekreśla szans współpracy z Zachodem, „Tydzień na Wschodzie”, 1 X 2008, nr 31, s. 2; idem, W. Konończuk, Eskalacja napięcia $w$ stosunkach rosyjsko-białoruskich, „Tydzień na Wschodzie”, 17 VI 2009, nr 22, s. 3-4.

82 E. Mironowicz, Polityka zagraniczna Białorusi. 1990-2010, Białystok 2011, s. 179. 